\title{
Employing a Transgenic Animal Model to Obtain Cementoblasts In Vitro
}

John A. D’Errico, ${ }^{*}$ Janice E. Berry, ${ }^{*}$ Hongjiao Ouyang, ${ }^{*}$ Christopher L. Strayhorn, ${ }^{*}$ Jolene J. Windle, ${ }^{\dagger}$ and Martha J. Somerman* ${ }^{*}$

Background: Proper formation of cementum, a mineralized tissue lining the tooth root surface, is required for development of a functional periodontal ligament. Further, the presence of healthy cementum is considered to be an important criterion for predictable restoration of periodontal tissues lost as a consequence of disease. Despite the significance of cementum to general oral health, the mechanisms controlling development and regeneration of this tissue are not well understood and research has been hampered by the lack of adequate in vitro experimental models.

Methods: In an effort to establish cementoblast cell populations, without the trappings of a heterogeneous population containing periodontal ligament (PDL) cells, cells were obtained from the root surface of first mandibular molars of OC-TAg transgenic mice. These mice contain the SV40 large T-antigen (TAg) under control of the osteocalcin (OC) promoter. Therefore, only cells that express $\mathrm{OC}$ also express TAg and are immortalized in vitro. Based on results of prior in situ studies, OC is expressed by cementoblasts during root development, but not by cells within the PDL. Consequently, when populations are isolated from developing molars using collagenase/trypsin digestion, only cementoblasts, not PDL cells, are immortalized and thus, will survive in culture.

Results: The resulting immortalized cementoblast population (OC/CM) expressed bone sialoprotein (BSP), osteopontin (OPN), and $\mathrm{OC}$, markers selective to cells lining the root surface. These cells also expressed type I and XII collagen and type I PTH/PTHrP receptor (PTH1R). In addition to expression of genes associated with cementoblasts, OC/CM cells promoted mineral nodule formation and exhibited a PTHrP mediated cAMP response.

Conclusions: This approach for establishing cementoblasts in vitro provides a model to study cementogenesis as required to enhance our knowledge of the mechanisms controlling development, maintenance, and regeneration of periodontal tissues. J Periodontol 2000;71:63-72.

\section{KEY WORDS}

\section{Periodontal ligament/growth and development; periodontal} regeneration; dental cementum/growth and development.

\footnotetext{
* Department of Periodontics/Prevention/Geriatrics, University of Michigan, Ann Arbor, MI

$\dagger$ Cancer Therapy and Research Center, University of Texas Health Science Center, San

Antonio, TX

† Department of Pharmacology, University of Michigan.
}

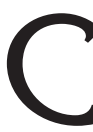
ementum was first described in $1835,{ }^{1}$ and research through the years has demonstrated that it is a unique tissue histologically, but shares many properties with other mineralized tissues, particularly bone..$^{2,3}$ Despite many years of research in which the importance of cementum in the reparative process following periodontal disease has been explored, ${ }^{4}$ very little is known about the cells responsible for formation of cementum, cementoblasts. The wealth of what is known about cementum comes from numerous studies on the histology and composition of this tissue. Light and electron microscopy have enabled classification of cementum into 5 different subtypes based on the presence or absence (cellular versus acellular) of cells and the source of collagen fibers (extrinsic versus intrinsic). $3,5,6$ All of these subtypes are quite different from bone, in that they are not innervated, exhibit little or no remodeling, and are avascular. Despite these differences, cementum does have many similarities to bone. First, diseases that affect the properties of bone often alter cementum's properties as well. For example, Paget's disease results in hypercementosis; hypophosphatasia results in no cementum formation with exfoliation of teeth; decreased cementum is associated with hypopituitarism; and defective cementum is seen in patients with cleidocranial dysplasia. Second, the composition of cementum is similar to that of bone. Cementum is approximately $50 \%$ hydroxyapatite and 50\% collagen and 
non-collagenous proteins. ${ }^{7}$ Protein extracts of mature cementum promote cell migration ${ }^{8}$ and attachment ${ }^{9-11}$ and stimulate protein synthesis of gingival fibroblasts and periodontal ligament cells. ${ }^{12,13}$ Investigation of these extracts revealed the presence of bone sialoprotein (BSP), ${ }^{14-16}$ osteopontin (OPN), 14,17,18 and fibronectin. 6,19

Immunocytochemistry ${ }^{16,17}$ and in situ hybridization $^{20}$ confirmed the presence of these proteins and further detected the presence of osteocalcin (OC), 20,21 vitronectin, ${ }^{22} \gamma$-carboxyglutamic acid, ${ }^{23}$ osteonectin, ${ }^{24}$ proteoglycans, ${ }^{25}$ and several growth factors. Two additional molecules, an adhesion molecule and a growth factor, have been identified and initial data suggest that they may be unique to cementum. Cementum attachment protein (CAP) ${ }^{26,27}$ may prove to be a cementum specific collagen-like molecule, while a factor initially named cementum derived growth factor (CGF) ${ }^{28}$ now considered to be an insulin-like growth factor (IGF-I like molecule), may be shown to have properties different from those of IGF-I.

In order to develop ideal clinical therapies to regenerate tissues lost to periodontal disease, it is necessary to understand the mechanisms involved in periodontal development and regeneration and, particularly, cementogenesis. These processes are not well understood and have been hampered by a lack of good in vitro models to study cementoblasts. Previously, our laboratory reported the successful isolation of a heterogeneous population of murine cementoblasts and periodontal ligament (PDL) cells. ${ }^{20}$ Cells within this population expressed type I collagen, BSP, OPN, and OC, mirroring the expression pattern seen in developing tissues. Of particular interest was the expression pattern noted for BSP and OC, which in situ is expressed selectively by cells lining the tooth root surface, cementoblasts, and not expressed, at any stage of development, by PDL cells. The presence of cells in vitro exhibiting these 2 markers indicated that cementoblasts were present in the population.

While these mixed CM/PDL populations represented a good first step in the establishment of an in vitro model system to study cementoblasts, the lack of markers for PDL cells made it difficult to eliminate PDL cells from these heterogeneous cell populations. In an effort to establish cementoblast cell populations, without the characteristics of a heterogeneous population containing PDL cells, we isolated cells from the root surface of first mandibular molars of OC-TAg transgenic mice. These mice carry the SV40 large T antigen (TAg) under control of the rat OC promoter. ${ }^{29}$ Therefore, only cells that express $O C$, that is cementoblasts, not PDL cells, can express TAg and are immortalized. Consequently, when cells are isolated from developing molars using collagenase/trypsin diges- tions, non-immortalized cells are eliminated with passage.

Here, we describe the isolation and characterization of cementoblasts in vitro. The resulting immortalized cementoblast population (OC/CM) expressed BSP, OPN, and OC, markers selective to cells lining the root surface. These cells also expressed type I and XII collagen and type I PTH/PTHrP receptor (PTH1R). In addition to expression of genes associated with cementoblasts, OC/CM cells promoted mineral nodule formation and exhibited a PTHrP mediated CAMP response.

\section{MATERIALS AND METHODS}

\section{Mouse Breeding Strategy}

The mice used (OC-TAg) contain a transgene, which consists of the protein coding region of SV-40 large Tand small t-antigens, under control of the rat osteocalcin gene promoter. ${ }^{29}$ To obtain transgenic progeny for cell isolation, founder transgenic mice were bred to non-transgenic CB6F1 mice. $\S$

The presence of the osteocalcin promoter driving the transgene insures that cells expressing osteocalcin (for our purposes, cementoblasts) are preferentially immortalized. All procedures involving mice were performed in compliance with regulations administered by the University of Michigan Unit for Lab Animal Medicine.

\section{Cell Culture and Cloning}

Day 40, 41, and 42 mice (day $0=$ vaginal plug, day $19=$ birth) were selected for cell isolation based on our previous data in situ ${ }^{15}$ and in vitro, ${ }^{20}$ which indicated that within this time span cells along the root surface, cementoblasts, express high levels of cementoblast markers: BSP and OC mRNA. This phenotype is maintained when cells are cultured.

In order to establish cementoblast cultures our previously published method for obtaining primary cultures of root surface cells was used. ${ }^{20}$ Briefly, 25 mandibles from transgenic mice (day 40 to 42) were dissected from surrounding tissues, rinsed with $0.12 \%$ chlorhexidine digluconatell for 30 seconds to minimize tissue contamination by oral flora, and then washed in Hank's balanced salt solution (HBSS). "Mandibles were hemisected by incision through the midline symphysis, and first molars were extracted using a dissecting microscope. Molars were removed by meticulously cutting into the periodontal ligament and thereby separating the PDL from surrounding alveolar bone (Fig. 1). Molars were rinsed with HBSS and then placed in HBSS until all dissections were completed, approximately 1 hour.

$\S$ Harlan Sprague Dawley, Inc., Indianapolis, IN.

$\|$ Peridex, Procter and Gamble, Cincinnati, OH.

II GIBCO-BRL, Gaithersburg, MD. 

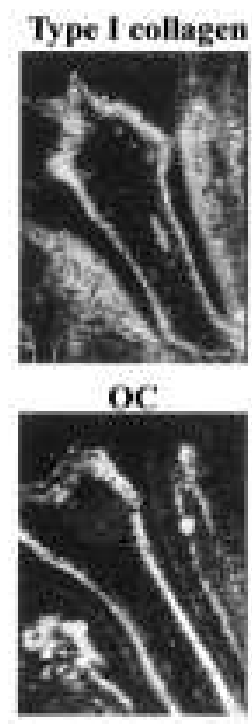
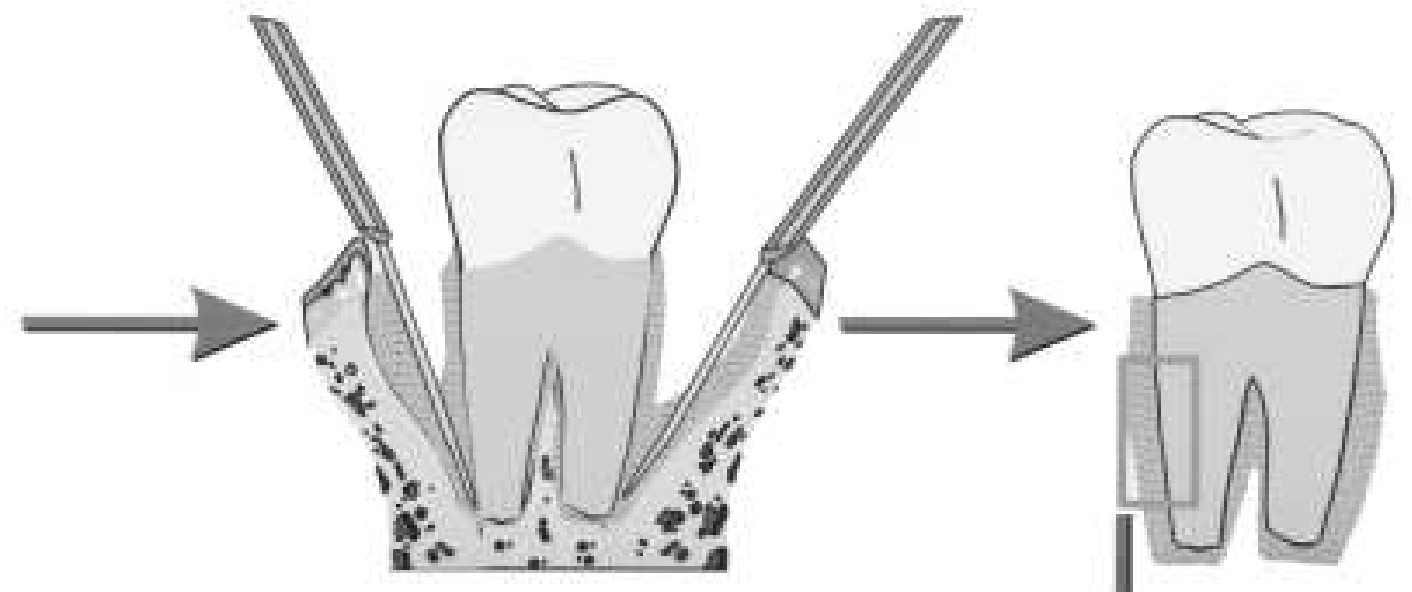

Isolated Cells
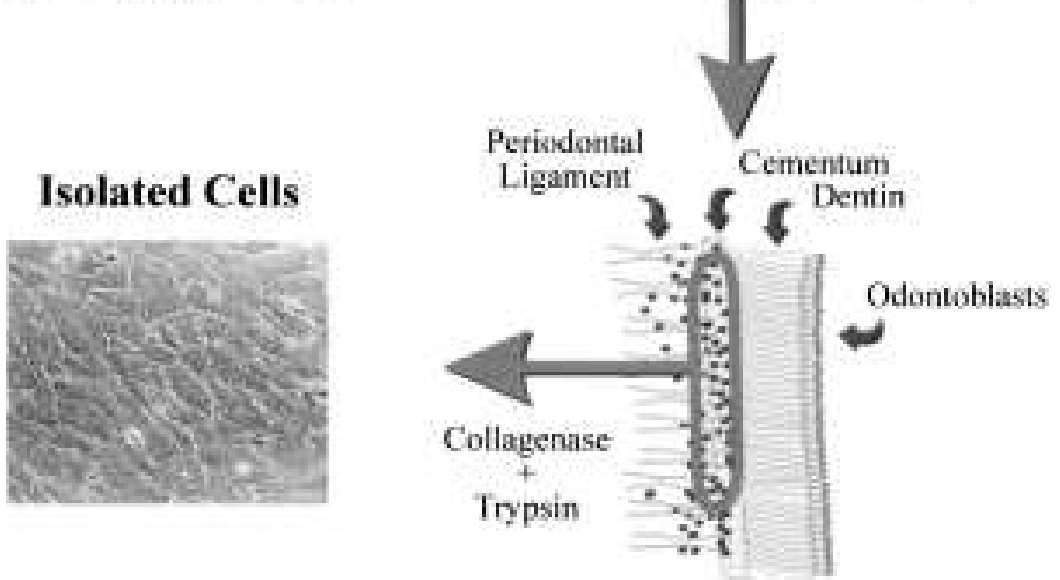

Characterization

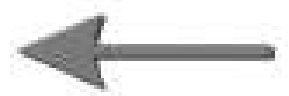

Figure I.

Strategy for obtaining cementoblasts in vitro. Marker genes for cementoblasts were identified in situ. Expression of markers was strongest at day 4 I of mouse development. Shown here is in situ for OC (osteocalcin) and type I collagen. Note OC expression is selective to root surface cells. Next mandibles were dissected from surrounding tissues, first molars extracted, and cells adherent to the root surface removed enzymatically. Cementoblasts, immortalized by TAg under the control of the OC promoter, survive in culture whereas PDL cells fail to survive with passage in vitro.

Techniques similar to those used previously for the isolation of calvaria osteoblasts and primary cementoblasts/periodontal ligament (CM/PDL) cells ${ }^{30-33}$ were used to isolate cells from molar surfaces. Briefly, molars with surrounding tissues were placed in phosphate buffered saline (PBS) containing 880u/ml Type VII high purity collagenase ${ }^{\#}$ and $0.25 \%$ trypsin ${ }^{\|}$and rotated for 10 minutes at $37^{\circ} \mathrm{C}$. Cells from this initial digest were discarded. Fresh collagenase/trypsin solution was added and tissues were rotated for 2 hours at $37^{\circ} \mathrm{C}$. The supernatant containing approximately 700,000 cells was pelleted at $300 \times \mathrm{g}$ for 10 minutes, and resuspended in $12 \mathrm{ml}$ DMEM containing 10\% fetal bovine serum (FBS), $100 \mathrm{u} / \mathrm{ml}$ penicillin, and $100 \mu \mathrm{g} / \mathrm{ml}$ streptomycin. Cells were plated in multi-well tissue culture treated dishes and incubated with $5 \% \mathrm{CO}_{2}$, at $37^{\circ} \mathrm{C}$. These cells are designated osteocalcin promoter cementoblast cells (OC/CM cells). In order to maintain viable cell populations, cells at passage 4 were subcloned by limiting dilution. Cells were plated into 96well tissue culture dishes at a concentration of 1 cell or fewer per well. Subclones from single cells were expanded and were analyzed at passage 3 or 4 for expression of cementoblast markers. These stock cell populations were used in the studies here or stored under liquid nitrogen for future studies.

\section{Northern Blotting}

Total cellular RNA was isolated using a modified guanidine thiocyanate procedure. ${ }^{34}$ RNA was denatured; size fractionated on a $6.7 \%$ formaldehyde, $1.2 \%$ agarose gel; transferred to a nylon membrane; ** and cross-linked by UV irradiation. ${ }^{\dagger \dagger}$

Blots were hybridized with random-primed ${ }^{32}$-P radiolabeled probes ${ }^{\ddagger \ddagger}$ and were exposed to Kodak XOMAT film at $-70^{\circ} \mathrm{C}$ with intensifying screens for 24 to 72 hours.

Probes used for Northern blots and in situ hybridization were: $\mathrm{BSP}=\mathrm{M}$-BSP consists of $1 \mathrm{~kb}$ of mouse

\footnotetext{
\# Sigma Chemical Company, St. Louis, MO.

** Duralon-UV, Stratagene, Inc., La Jolla, CA.

$\dagger \dagger$ Stratalinker, Stratagene, Inc.




CDNA in PCR $\mathrm{II}^{35}$ (a gift from Dr. M. Young, $\mathrm{NIH} / \mathrm{NIDCR}$ ); OC $=400 \mathrm{bp}$ of mouse OC cDNA originally cloned into pSP65 cloning vector was transferred to Bluescript SK; ${ }^{36}$ OPN $=$ MOP-3 consists of $1 \mathrm{~kb}$ of mouse OPN cDNA in PCR II ${ }^{37}$ (a gift from Dr. M. Young, NIH/NIDCR); Type I collagen = consists of $1 \mathrm{~kb}$ of bovine type I collagen cloned into Bluescript (a gift from Dr. M. Young, NIH/NIDCR); Type XII collagen = contains 400 bp of the carboxyl region of mouse type XII collagen cDNA cloned into Bluescript ${ }^{38}$ (a gift from Drs. S. P. Oh and B. Olsen, Harvard University); Type I PTH/PTHrP receptor $(\mathrm{PTH} 1 \mathrm{R})=1.6 \mathrm{~kb}$ encoding the full-length rat bone receptor ${ }^{39}$ (a gift from Dr. L. McCauley, U of MI).

\section{In situ Hybridization}

Standard in situ hybridization procedures were used, ${ }^{40}$ with slight modifications. ${ }^{20}$ Tissues were fixed in Bouin's fixative (acetic acid, formaldehyde, and picric acid), decalcified as needed, and imbedded in paraffin. Six $\mu M$ sections were mounted on silane treated slides. For in situ hybridization, slides were deparaffinized and rehydrated, followed by a 30-minute treatment at $37^{\circ} \mathrm{C}$ with $10 \mu \mathrm{g} / \mathrm{ml}$ proteinase $\mathrm{K}$. The rest of the in situ hybridization procedure was the same as that for cells described below.

Cells grown on chamber slides were fixed with $2 \%$ paraformaldehyde and $0.2 \%$ triton, acetylated, and dehydrated using increasing concentrations of ethanol. Slides were overlaid with a hybridization solution containing $50 \%$ formamide, $1 \mathrm{X}$ hybridization buffer (10 mM Tris, 0.3M NaCl, 1 mM EDTA, pH 7.5), 1X Denhardt's solution, $0.02 \%$ bovine serum albumin, 100 $\mu \mathrm{g} / \mu \mathrm{l}$ sheared salmon sperm DNA, $500 \mu \mathrm{g} / \mathrm{ml}$ of tRNA, $10 \mathrm{mM}$ dithiothreitol (DTT), 10\% dextran sulfate, and $10^{6} \mathrm{cpm}$ of probe/ $100 \mu \mathrm{l}$, and hybridization was performed overnight at $50^{\circ} \mathrm{C}$ in a humid chamber. Both antisense and sense (control) RNA probes were transcribed from cDNA plasmids (see above) incorporating ${ }^{35}$ S-UTP. $\$ \S$ Unincorporated isotope was removed using G-50 sephadex spin columns $1 \| 1$ and probes were reduced to an average size of 150 to 500 bp by limited alkaline hydrolysis.

After post-hybridization washes in 4X SSC, cells were treated with RNase A, washed sequentially with decreasing concentrations of SSC containing $1 \mathrm{mM}$ DTT, and then incubated in 0.1X SSC with $1 \mathrm{mM}$ DTT at $60^{\circ} \mathrm{C}$ for 30 minutes. Following the high stringency incubation, slides were dehydrated quickly in ascending concentrations of ethanol, dried, and exposed to $\mathrm{X}$-ray film ${ }^{\text {III }}$ for 1 to 3 days to determine efficiency of hybridization. Slides were then coated with NTB-2 emulsion $^{\# \#}$ and stored desiccated in a dark container at $4^{\circ} \mathrm{C}$ for an appropriate time, determined by X-ray film results, usually 1 week to 1 month. Slides were developed using Kodak D-19 developer and rapid fixer and were counterstained with hematoxylin/eosin. Hybridization signal was visualized using a light microscope with dark and light field condensers.

\section{Mineralization Assay}

Mineralization assays were performed as previously described. ${ }^{41,42}$ Briefly, cells were plated in 24-well tissue culture treated dishes at a density of $5 \times 10^{4} / \mathrm{cm}^{2}$ and were grown for 7 or 14 days. Control wells received DMEM with $10 \%$ FBS and antibiotics, while experimental wells were fed for 14 days with above media plus $50 \mu \mathrm{g} / \mathrm{ml}$ ascorbic acid and $\beta$-glycerophosphate. In some situations, a 7-day assay was utilized and in place of $\beta$-glycerophosphate, inorganic phosphate at concentrations from 1.5 to $4.0 \mathrm{mM}$, was added for the final 2 days. At the conclusion of the incubation, cells were fixed in methanol and stained for detection of mineral nodules using the von Kossa method.

\section{Attachment Assay}

A modification of the Klebe assay was used to determine the ability of specific proteins to promote attachment of cells. ${ }^{43}$ Untreated 24 -well dishes were coated with $400 \mu \mathrm{l}$ of putative attachment agents at a concentration of $20 \mu \mathrm{g} / \mathrm{ml}$ in water. Agents included fibronectin $\S \S$ and guanidine/EDTA extracts of bovine bone, bovine dentin, and human cementum. Mineralized tissue extracts were prepared using methods described previously, where extracts were obtained by sequential extraction in $50 \mathrm{mM}$ Tris $\mathrm{HCl}$ (pH 7.4) containing $4 \mathrm{M}$ guanidine $\mathrm{HCl}$ with protease inhibitors at $4^{\circ} \mathrm{C}$ for 1 week, followed by $4 \mathrm{M}$ guanidine $\mathrm{HCl}$ with $0.5 \mathrm{M}$ EDTA with protease inhibitors at $4^{\circ} \mathrm{C}$ until tissues were demineralized. ${ }^{12,44}$ Extracts were concentrated, dialyzed, and lyophilized before being dissolved in distilled water for use in assays. Water was used as a control for these experiments.

Dishes were dry coated, and wells were preincubated at $37^{\circ} \mathrm{C}$ with $400 \mu \mathrm{l}$ DMEM containing $1 \mathrm{mg} / \mathrm{ml}$ bovine serum albumin (BSA) with and without 100 $\mu \mathrm{g} / \mathrm{ml}$ RGD peptide (RGDSPA peptide, University of Michigan Core Facilities). After 1 hour preincubation, $2 \times 10^{4}$ cells in $100 \mu \mathrm{l}$ DMEM/BSA were added to each of the wells and incubated for 2 hours. Morphology and cell spreading were assessed microscopically and then wells were rinsed in $500 \mu \mathrm{l}$ HBSS to remove unattached cells. Adherent cells were removed enzymatically and counted.***

\section{PTHrP-Mediated cAMP Stimulation Assay}

The CAMP stimulation assay was performed as described previously. ${ }^{45} \mathrm{OC} / \mathrm{CM}$ cells, rat osteosarcoma cells (ROS 17/2.8), or human PDL cells were seeded

$\S \S$ Riboprobe Gemini System, Promega Biotech, Madison, WI.

|l|| Select-D, 5 prime -3 prime, Boulder, CO.

If Hyperfilm- $\beta$ max, Amersham-Pharmacia, Arlington Heights, IL.

\#\# Kodak Imaging Systems, Rochester, NY.

*** Coulter Electronics, Miami, FL. 
at $5 \times 10^{4}$ cells $/ \mathrm{cm}^{2}$ in triplicate wells of 24-well tissue culture treated plates. ROS $17 / 2.8$ cells were used as positive controls, since they exhibit a PTH/PTHrP mediated CAMP response, ${ }^{46}$ and human PDL cells, which demonstrate minimal PTH/ PTHrP response, ${ }^{47}$ were used as negative controls. At confluency, cells were treated with either $0.1 \mu \mathrm{m}$ human PTHrP (1-34) or vehicle (4 $\mathrm{mM} \mathrm{HCl} / 0.1 \% \mathrm{BSA}$ ) for 10 minutes at $37^{\circ} \mathrm{C}$ in HBSS without calcium and magnesium with $0.1 \% \mathrm{BSA}$ and $1 \mathrm{mM}$ 3-isobutyl-1-methylxanthine (IBMX), " a phosphodiesterase inhibitor. Media were aspirated and cold 5\% perchloric acid was added to each well. Plates were stored overnight at $-20^{\circ} \mathrm{C}$ for cAMP extraction, then samples were neutralized with $4 \mathrm{~N} \mathrm{KOH}$ and centrifuged. Supernatants were assayed for cAMP content using a cAMP binding protein assay employing ${ }^{3} \mathrm{H}$ labelled $\mathrm{CAMP} \mathrm{P}^{\dagger \dagger}$ as a competitor for endogenous CAMP binding.

cAMP concentration in samples was calculated by log-logit transformation, ${ }^{\neq} \neq \ddagger$ normalized to cell number (parallel wells were run for cell count using a counter), *** and values were expressed as $\mathrm{pmol} / 10^{5}$ cells. Data were further analyzed using unpaired Student $t$-test. ${ }^{\ddagger \dagger}$

\section{Statistical Analysis}

Statistical analysis of attachment data was performed using ANOVA and Tukey-Kramer multiple comparison tests using computer software. ${ }^{\neq \ddagger}$ The data are represented as mean \pm standard deviation, and significance $(P \leq 0.001)$ is denoted with an asterisk.

\section{RESULTS}

\section{Characterization of Tissues In Situ}

Prior to isolating cementoblasts from OC-TAg mice it was necessary to establish that these cells exhibited the same profile in situ as established previously for non-transgenic, CD-1 mice. ${ }^{15,16,20}$ As seen in Figure 1 , murine molar tissues obtained from OC-TAg mice at day 41 exhibited the same OC profile noted for CD1 mice, where $\mathrm{OC}$ was expressed selectively by cells lining the tooth root and the surrounding alveolar bone, but not by cells within the PDL space. OC transcripts were noted in odontoblasts as well. Also, as noted for CD-1 mice, type I collagen was expressed throughout the PDL. The expression patterns for BSP and OPN were as noted for CD-1 mice, where at day 41 BSP and

OPN were expressed by cells along the root surface but not within the PDL region (data not shown).

\section{Morphological Analysis}

Morphologically, cells obtained from molar tissues at day 41 of development, designated OC/CM cells, exhibited a cuboidal appearance and this was noted throughout the culture (Fig. 1). Next, studies were designed to determine if OC/CM cells exhibited characteristics reported for primary heterogeneous cultures of cementoblasts and PDL cells ${ }^{20}$ and, thus, to confirm that these immortalized cells were appropriate for use in investigations aimed at defining the properties of cementoblasts.

\section{Gene Expression}

To ensure that expression of TAg did not significantly alter expression of other genes associated with cementoblasts northern hybridization was used. As demonstrated in Figure 2, OC/CM cells expressed BSP, OC, OPN, type I and XII collagen, and PTH1R. This expression profile mirrored that reported for primary cells, ${ }^{20}$ indicating that the process of immortalization had not affected the characteristics of these cells. Additionally, gene expression was monitored routinely with cell passage, and no significant differences in expression profiles was noted between passages. T-antigen expres-

$\dagger \dagger \dagger$ ICN, Costa Mesa, CA

㧊 GraphPad Software, San Diego, CA. 
sion has been maintained in cells with passage (data not shown).

\section{Mineralization}

As a next step in characterizing properties of OC/CM cells, the ability of the cells to induce biomineralization was determined using von Kossa stain. As seen in Figure 3A, OC/CM cells stimulated mineral nodule formation within 14 days using $\beta$-glycerol phosphate. Further, in examination of cells by phase contrast microscopy (unstained cells), nodule formation was noted as early as day 5 . Therefore, additional studies were designed to determine if mineralization occurred more rapidly than 14 days and if mineralization was dependent on phosphate concentration. As evident in Figure 3B, OC/CM cells induced formation of mineral nodules in a dose-dependent fashion, using inorganic phosphate, within 7 days, where a concentration as low as $1.5 \mathrm{mM} \mathrm{P}_{\mathrm{i}}$ promoted mineral formation as assayed by von Kossa.

\section{Attachment Assay}

Since regeneration of the periodontium is dependent upon attachment of appropriate cells at the healing site, the capacity of protein extracts derived from 3 mineralized tissues, bone, cementum and dentin, to promote attachment of OC/CM cells was assessed. All protein extracts promoted cell attachment $(P<0.001)$ in an RGD dependent fashion, suggesting the involvement of integrins in this process (Fig. 4). Cell attachment was also promoted by fibronectin; however, the

A

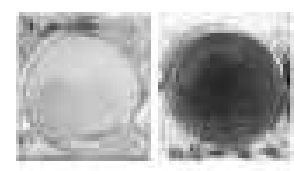

B

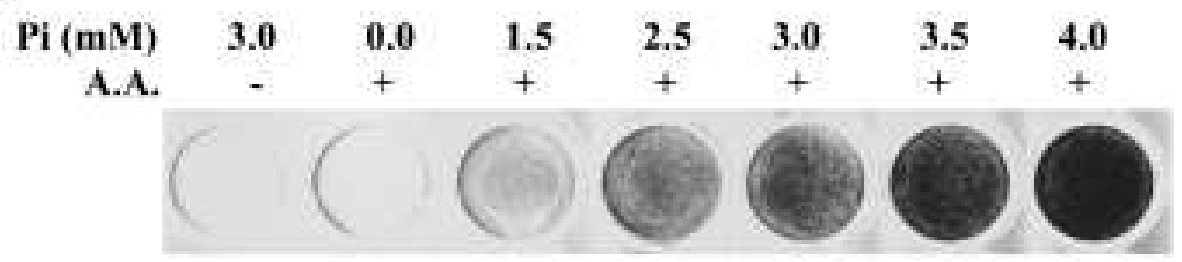

Figure 3.

Mineralization assays in vitro. A. OCICM cells were grown in control DMEM medium containing $10 \%$ FCS and $50 \mathrm{\mu g} / \mathrm{ml}$ ascorbic acid (left panel, control) or medium containing $10 \% \mathrm{FCS}, 50 \mathrm{\mu g} / \mathrm{ml}$ ascorbic and B-glycerolphosphate (right panel) for 14 days and then stained for mineral nodules by von Kossa assay. Black stain indicates calcium phosphate deposits. B. OC/CM cells were cultured in DMEM containing $10 \%$ FCS and $3.0 \mathrm{mM}$ inorganic phosphate added on day 5 (control) or DMEM containing $10 \%$ FCS, $50 \mathrm{\mu g} / \mathrm{ml}$ ascorbic acid for 7 days and increasing concentrations of inorganic phosphate ( 0 to $4.0 \mathrm{mM}$ ) added on day 5 and then stained by von Kossa on day 7 to determine mineral nodules. ability of RGD peptide to block fibronectin mediated attachment was not as pronounced when compared with their effect on protein extracts of bone, cementum, or dentin-mediated cell attachment, suggesting that fibronectin-directed cell attachment may involve regions in addition to the RGD domain.

\section{PTHrP-Mediated cAMP Stimulation}

As anticipated from in situ studies examining molar tissues during murine development, the PTH1R was present in cultured cementoblasts (Fig. 2). Therefore, the ability of these cells to respond to PTHrP ${ }^{1,34}$ was determined. As noted in Figure 5, PTHrP was able to enhance cAMP levels by greater than 10 -fold, in both the ROS17/2.8 (control) and in OC/CM cells. In contrast, PDL cells were not responsive to PTHrP (data not shown).

\section{DISCUSSION}

Previously, our laboratory reported on the isolation and characterization of a mixed population of murine cells containing cementoblasts and PDL (CM/PDL) cells. ${ }^{20}$ The procedure used to establish this population was designed to isolate functional cementoblasts along with PDL cells while excluding osteoblasts from the surrounding alveolar bone. Gene expression analysis indicated that cells within the CM/PDL population expressed mRNAs for alkaline phosphatase and Type I and XII collagens, as well as transcripts for BSP, OC, and OPN, indicative of the presence of cementoblasts in the population. ${ }^{20}$

While results of this previous study demonstrated that functional cementoblasts could be isolated and characterized in vitro, concerns existed regarding the use of $\mathrm{CM} / \mathrm{PDL}$ cell populations in selected studies. First, CM/PDL cells did not survive continued passage and therefore did not provide an in vitro model for extensive analysis of the cellular and molecular properties of cementoblasts. Second, this population contained both cementoblasts and PDL cells. This heterogeneous population may prove advantageous for certain procedures since it reflects the cell types considered to be involved in periodontal wound healing; however, this cell heterogeneity presents uncertainties for studies focused on cementoblasts specifically. Therefore, alternative strategies were deemed neccessary for isolating and culturing cementoblasts independent of PDL cells. Fortunately, during the 


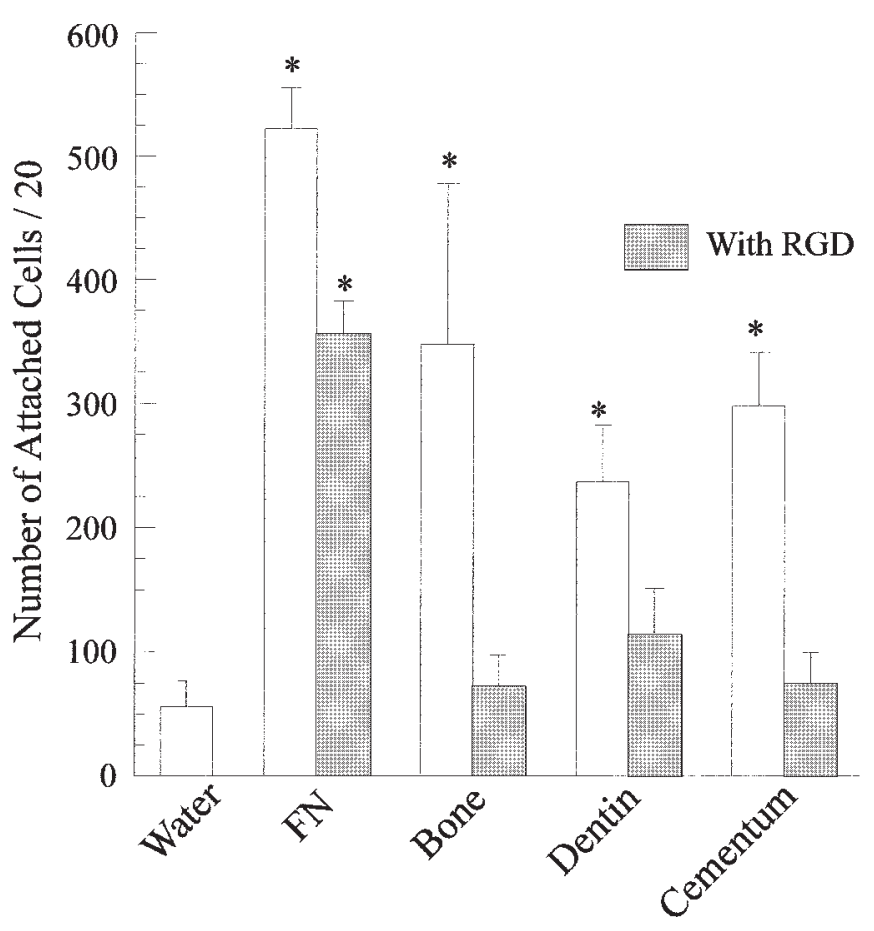

Figure 4.

Fibronectin (FN) and guanidine-EDTA extracts of bone, dentin, and cementum $(20 \mu \mathrm{g} / \mathrm{ml})$ enhanced the attachment of OC/CM cells when compared to water control. RGD peptide $(100 \mu \mathrm{g} / \mathrm{ml})$ was able to prevent significant attachment of OC/CM cells to all guanidine-EDTA extracts. Cell attachment to FN, while decreased by addition of RGD peptide, was still significant when compared to water control. Data are represented as mean \pm standard deviation and significance $(\mathrm{P} \leq 0.01)$ is denoted by an asterisk (*).

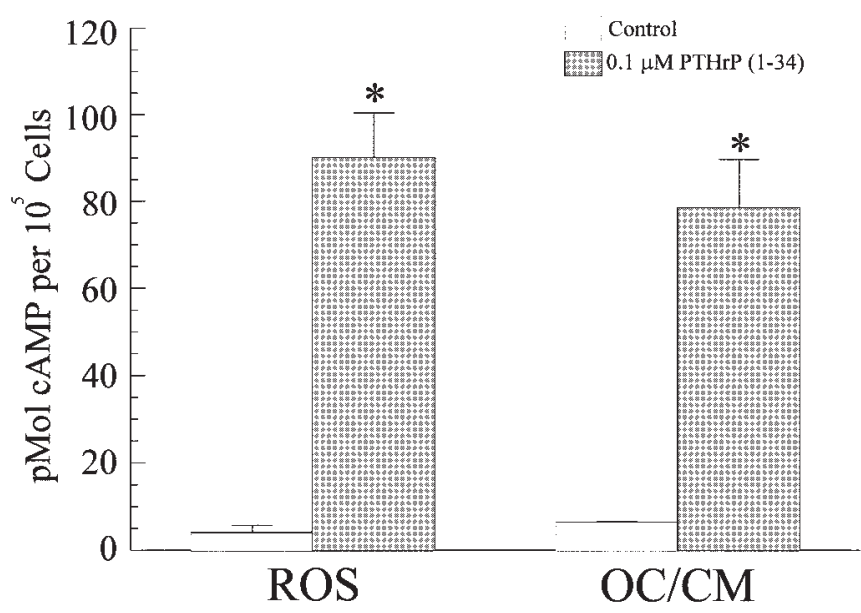

Figure 5.

PTHrP mediated CAMP response. Cells were treated with $10^{-7} \mathrm{M}$ PTHrP ( I-34) (solid bar) or vehicle (open bar) for 15 minutes and then intracellular CAMP levels determined. (ROS 17/2.8 rat osteosarcoma cells served as positive control). Data were normalized to $10^{5}$ cells and data are represented as mean \pm standard deviation and significance $(\mathrm{P} \leq 0.0 \mathrm{I})$ denoted by an asterisk (*). course of our studies, Chen et al. reported success in isolating and maintaining immortalized osteoblasts in vitro using an OC-TAg transgenic mouse model. ${ }^{29}$ In OC-TAg mice, TAg expression is under control of the $\mathrm{OC}$ promoter and thus only cells expressing $\mathrm{OC}$ will survive in culture. The selective expression of $O C$ by cementoblasts and not by PDL cells allowed the use of these mice for isolating immortalized cementoblasts without contamination by PDL cells (Fig. 1).

Results of investigations presented here indicate that OC/CM cells express the following genes as demonstrated by northern hybridization: Type I and XII collagens, PTH1R, BSP, OPN, and OC as demonstrated by northern hybridization. All of these genes have been implicated as playing a role in regulating cementogenesis. Type I and XII collagens, while not specific to cementum, are expressed in mineralized tissues and ligaments. ${ }^{48-51}$ As discussed below, expression of PTH1R by cementoblasts and their responsiveness to PTH/PTHrP may be significant to early stages of tooth development and eruption. ${ }^{52-56}$ BSP and OC, expressed by cementoblasts in situ, ${ }^{15-17,20,21}$ are major components of cementum ${ }^{11,21}$ and are considered excellent markers for mineralized tissue-specific cells. Existing evidence suggests that BSP plays a critical role in the initiation of biomineralization. ${ }^{17,31,57-62}$ In addition, BSP contains an RGD cell attachment region ${ }^{11,63}$ and is thought to be involved in mediating cell attachment in vivo. Suggested functions for OPN in mineralized tissues include controlling migration and attachment of osteoblasts and osteoclasts and regulating crystal growth. ${ }^{59,61,64-66} \mathrm{OC}$ is expressed by osteoblasts, cementoblasts, and odontoblasts, and increased serum $O C$ levels correlate with bone cell synthesis and bone formation. ${ }^{32,67}$ Studies by Ducy et al. ${ }^{68}$ indicate that transgenic mice lacking OC gene develop a phenotype marked by enhanced mineral density, thus suggesting that $O C$ may be a regulator of mineral formation. Expression of these markers by $\mathrm{OC} / \mathrm{CM}$ cells provides strong evidence that these are cementoblasts.

While the establishment of immortalized cultures expressing markers selective to the tooth root surface was a critical first step for developing an in vitro model to study cementoblasts and cementogenesis, additional analyses were required to determine if these cells exhibited properties attributed to cementoblasts. As a next step, the ability of these cells to induce mineral formation in vitro was determined. As evident in Figure $3 \mathrm{~B}, \mathrm{OC} / \mathrm{CM}$ cells promoted mineral nodule formation in a dose-dependent fashion, where a concentration of inorganic phosphate as low as $1.5 \mathrm{mM}$ promoted mineral formation as assayed by von Kossa. While additional studies are required to demonstrate that this is true mineral formation, it is impressive to note that mineralization was rapid, with a robust 
response noted within 7 days. In contrast, previous studies with human PDL cells, ${ }^{41,69}$ including those from our laboratory, indicated that while PDL cells promoted mineralization, it required a much longer time to do so; i.e., approximately 3 weeks. While speculative at this time, the rapid induction of mineralization demonstrated by OC/CM cells may be related to strong BSP expression observed by these cells in vivo ${ }^{15,16,20}$ and in vitro. ${ }^{20}$ In contrast to OC/CM cells, BSP expression is minimal, if detectable, in PDL cells in vivo ${ }^{15,16,20}$ and in vitro 69,70 and may explain the length of time needed for PDL cells to induce mineralization.

Next, since OC/CM cells expressed PTH1R mRNA, the responsiveness of these cells to PTHrP was determined. The results here demonstrated that OC/CM cells respond to PTHrP as measured by increased cAMP levels, suggesting that PTHrP may regulate activity of cells within the PDL region. This response was of specific interest due to the accumulating evidence that PTHrP may regulate early stages of tooth development and tooth eruption. PTHrP mRNA and the associated type I receptor have been identified within developing periodontal tissues ${ }^{52-54}$ and PTH/PTHrP has been shown to enhance both tooth eruption and orthodontic tooth movement. ${ }^{55,56}$ In addition, strains of mice that are PTHrP deficient exhibit failure of tooth eruption and abnormal periodontal formation. ${ }^{54,71,72}$ Therefore, having a population of cementoblasts in vitro that are responsive to PTHrP will be valuable for future studies targeted at determining the function of this peptide during tooth development.

Finally, the ability of protein extracts derived from mineralized tissues to promote cell attachment was determined. Guanidine-EDTA extracts of mineralized tissues are known to contain proteins bound to the mineral phase and, thus, these proteins are considered to have an important role in the regulation of mineral formation. Guanidine-EDTA extracts of bone, dentin, and cementum have been shown previously to promote attachment of cells of mesenchymal origin ${ }^{73}$ and these extracts were also able to promote attachment of OC/CM cells. While this attachment is not phenotype specific, the ability of OC/CM cells to attach to matrix proteins derived from cementum and dentin may be significant since an important aspect of cementogenesis, both during development and during wound healing/regeneration, is having a critical number of active cells at the local site. Fibronectin also promoted attachment of OC/CM cells, where this molecule is known to promote attachment of several cell types including mesenchymal cells and epithelial cells. ${ }^{74-76}$ Clinical trials have included the application of fibronectin to root surfaces in an effort to promote cell adhesion. Unfortunately, results of these trials have not been promising, ${ }^{77}$ and thus additional studies targeted at identifying molecules that promote adhesion of cementoblast-like cells versus epithelial cells are of importance for the development of agents that will attract cells to the healing site.

In summary, OC/CM cells represent a unique model system to study the cellular and molecular biology of cementoblasts with the aim of furthering our understanding of cementogenesis. Experiments using these important cells in vitro will enable us to employ innovative approaches to determine whether cementoblasts express "unique" proteins and/or exhibit a different protein profile, when compared with osteoblasts, odontoblasts, ameloblasts, or epithelial root sheath cells. We anticipate that data from such studies will provide information as to the origin of cementoblasts and suggest factors/proteins that will advance the field of periodontal regeneration, resulting in enhanced regenerative therapies.

\section{ACKNOWLEDGMENT}

This study was supported by NIDCR/NIH grants DE05685, DE09532, and DE13047.

\section{REFERENCES}

1. Denton GB. The discovery of cementum. J Dent Res 1939;18:239-242.

2. Tenorio D, Cruchley A, Hughes FJ. Immunocytochemical investigation of the rat cementoblast phenotype. J Periodont Res 1993;28:411-419.

3. Schroeder HE. Human cellular mixed stratified cementum: a tissue with alternating layers of acellular extrinsic- and cellular intrinsic fiber cementum. Schweiz Monatsschr Zahnmed 1993;103:550-560.

4. Knox B, Aukhil I. Ultrastructural study of experimental cementum regeneration in rats. J Periodont Res 1988;23: 60-67.

5. Bosshardt D, Schroeder HE. Evidence for rapid multipolar and slow unipolar production of human cellular and acellular cementum matrix with intrinsic fibers. $J$ Clin Periodontol 1990;17:663-668.

6. Yamamoto T, Domon T, Takahashi S, Wakita M. Comparative study of the initial genesis of acellular and cellular cementum in rat molars. Anat Embryol (Berlin) 1994;190:521-527.

7. Birkedal-Hansen H, Butler WT, Taylor RE. Proteins of the periodontium. Characterization of the insoluble collagens of bovine dental cementum. Calcif Tissue Res 1977;23:39-44.

8. Nishimura K, Hayashi M, Matsuda K, Shigeyama Y, Yamasaki A, Yamaoka A. The chemoattractive potency of periodontal ligament, cementum and dentin for human gingival fibroblasts. J Periodont Res 1989;24:146-148.

9. Melcher AH, Cheong T, Cox J, Nemeth E, Shiga A. Synthesis of cementum-like tissue in vitro by cells cultured from bone: a light and electron microscope study. J Periodont Res 1986;21:592-612.

10. Somerman MJ, Morrison GM, Alexander MB, Foster RA. Structure and composition of cementum. In: Bowen W, Tabak L, eds. Cariology of the 1990s. New York: University of Rochester Press; 1993:155-171.

11. Somerman MJ, Sauk JJ, Foster RA, Norris K, Dickerson K, Argraves WS. Cell attachment activity of cementum: bone sialoprotein II identified in cementum. J Periodont Res 1991;26:10-16. 
12. Somerman MJ, Archer SY, Hassell TM, Shteyer A, Foster RA. Enhancement by extracts of mineralized tissues of protein production by human gingival fibroblasts in vitro. Arch Oral Biol 1987;32:879-883.

13. Somerman MJ, Archer SY, Shteyer A, Foster RA. Protein production by human gingival fibroblasts is enhanced by guanidine EDTA extracts of cementum. $J$ Periodont Res 1987;22:75-77.

14. Lekic P, Sodek J, McCulloch CA. Osteopontin and bone sialoprotein expression in regenerating rat periodontal ligament and alveolar bone. Anat Rec 1996;244:50-58.

15. MacNeil RL, Berry JE, Strayhorn CL, Somerman MJ. Expression of bone sialoprotein mRNA by cells lining the mouse tooth root during cementogenesis. Arch Oral Biol 1996;41:827-835.

16. MacNeil RL, Sheng N, Strayhorn C, Fisher LW, Somerman MJ. Bone sialoprotein is localized to the root surface during cementogenesis. J Bone Miner Res 1994;9: 1597-1606.

17. McKee MD, Zalzal S, Nanci A. Extracellular matrix in tooth cementum and mantle dentin: localization of osteopontin and other noncollagenous proteins, plasma proteins, and glycoconjugates by electron microscopy. Anat Rec 1996;245:293-312.

18. MacNeil RL, Berry J, D'Errico J, Strayhorn C, Somerman MJ. Localization and expression of osteopontin in mineralized and nonmineralized tissues of the periodontium. Ann NY Acad Sci 1995;760:166-176.

19. Lukinmaa PL, Mackie EJ, Thesleff I. Immunohistochemical localization of the matrix glycoproteins tenascin and the ED-sequence-containing form of cellular fibronectin - in human permanent teeth and periodontal ligament. J Dent Res 1991;70:19-26.

20. D'Errico JA, MacNeil RL, Takata T, Berry JE, Strayhorn CL, Somerman MJ. Expression of bone associated markers by tooth root lining cells, in situ and in vitro. Bone 1997;20:117-126.

21. Takano-Yamamoto T, Takemura T, Kitamura Y, Nomura S. Site-specific expression of mRNAs for osteonectin, osteocalcin, and osteopontin revealed by in situ hybridization in rat periodontal ligament during physiological tooth movement. J Histochem Cytochem 1994;42:885-896.

22. Matsuura M, Herr Y, Han KY, Lin WL, Genco RJ, Cho MI. Immunohistochemical expression of extracellular matrix components of normal and healing periodontal tissues in the beagle dog. J Periodontol 1995;66:579-593 erratum: 1995;66:905.

23. Glimcher MJ. The nature of the mineral component of bone and the mechanism of calcification. Instr Course Lect 1987;36:49-69.

24. Tung PS, Domenicucci C, Wasi S, Sodek J. Specific immunohistochemical localization of osteonectin and collagen types I and III in fetal and adult porcine dental tissues. J Histochem Cytochem 1985;33:531-540.

25. Bartold PM, Reinboth B, Nakae H, Narayanan AS, Page RC. Proteoglycans of bovine cementum: isolation and characterization. Matrix 1990;10:10-19.

26. Olson S, Arzate H, Narayanan AS, Page RC. Cell attachment activity of cementum proteins and mechanism of endotoxin. J Dent Res 1991;70:1272-1277.

27. Wu D, Ikezawa K, Parker T, Saito M, Narayanan AS. Characterization of a collagenous cementum-derived attachment protein. J Bone Miner Res 1996;11:686-692.

28. Yonemura K, Narayanan AS, Miki Y, Page RC, Okada H. Isolation and partial characterization of a growth factor from human cementum. Bone Miner 1992;18:187-198.
29. Chen D, Chen H, Feng JQ, et al. Osteoblastic cell lines derived from a transgenic mouse containing the osteocalcin promoter driving SV40 T-antigen. Mol Cell Differentiation 1995;3:193-212.

30. Ritter NM, Farach-Carson MC, Butler WT. Evidence for the formation of a complex between osteopontin and osteocalcin. J Bone Miner Res 1992;7:877-885.

31. Chen J, Shapiro HS, Sodek J. Developmental expression of bone sialoprotein mRNA in rat mineralized connective tissues. J Bone Miner Res 1992;7:987-997.

32. Stein GS, Lian JB. Molecular mechanisms mediating proliferation/differentiation interrelationships during progressive deveopment of the osteoblast phenotype. Endocr Rev 1993;14:424-442.

33. Robey PG. Collagenase-treated trabecular bone fragments: a reproducible source of cells in the osteoblastic lineage. Calcif Tissue Int 1995;56 (Suppl. 1):S11-S12.

34. Xie WQ, Rothblum LI. Rapid, small-scale RNA isolation from tissue culture cells. Biotechniques 1991;11:324, 326-327.

35. Young MF, Ibaraki K, Kerr JM, Lyu MS, Kozak CA. Murine bone sialoprotein (BSP): cDNA cloning, mRNA expression, and genetic mapping. Mamm Genome 1994;5:108-111.

36. Celeste AJ, Rosen V, Bueker JL, Kriz R, Wang EA, Wozney JM. Isolation of the human gene for bone gla protein utilizing mouse and rat cDNA clones. EMBO $\mathrm{J}$ 1986;5:1885-1890.

37. Young MF, Kerr JM, Termine JD, et al. cDNA cloning, mRNA distribution and heterogeneity, chromosomal location, and RFLP analysis of human osteopontin (OPN). Genomics 1990;7:491-502.

38. Oh SP, Taylor RW, Gerecke DR, Rochelle JM, Seldin MF, Olsen BR. The mouse alpha 1 (XII) and human alpha 1 (XII)-like collagen genes are localized on mouse chromosome 9 and human chromosome 6. Genomics 1992; 14:225-231.

39. Kong XF, Schipani E, Lanske B, et al. The rat, mouse and human genes encoding the receptor for parathyroid hormone and parathyroid hormone-related peptide are highly homologous Biochem Biophys Res Commun 1994;200:1290-1299 (erratum: 1994;201:1058).

40. Ausubel FM, Brent R, Kingston RE, et al. Current Protocols in Molecular Biology. Boston: Massachusetts General Hospital, Harvard Medical School; 1993:14.0.114.5.5.

41. Arceo N, Sauk JJ, Moehring J, Foster RA, Somerman MJ. Human periodontal cells initiate mineral-like nodules in vitro. J Periodontol 1991;62:499-503.

42. Puchtler H, Meloan SN. Demonstration of phosphates in calcium deposits: a modification of von Kossa's reaction. Histochem 1978;56:177-185.

43. Klebe RJ. Isolation of a collagen-dependent cell attachment factor. Nature 1974;250:248-251.

44. Takata T, D'Errico JA, Atkins KB, et al. Protein extracts of dentin affect proliferation and differentiation of osteoprogenitor cells in vitro. J Periodontol 1998;69:12471255.

45. McCauley LK, Koh AJ, Beecher CA, Cui Y, Rosol TJ, Franceschi RT. PTH/PTHrP receptor is temporally regulated during osteoblast differentiation and is associated with collagen synthesis. J Cell Biochem 1996;61:638-647.

46. McCauley LK, Beecher CA, Melton ME, et al. Transforming growth factor-beta1 regulates steady-state PTH/PTHrP receptor mRNA levels and PTHrP binding in ROS 17/2.8 osteosarcoma cells. Mol Cell Endocrinol 1994;101:331-336. 
47. Nohutcu RM, Somerman MJ, McCauley LK. Dexamethasone enhances the effects of parathyroid hormone on human periodontal ligament cells in vitro. Calcif Tissue Int 1995;56:571-577.

48. Karimbux NY, Rosenblum ND, Nishimura I. Site-specific expression of collagen I and XII mRNAs in the rat periodontal ligament at two developmental stages. J Dent Res 1992;71:1355-1362.

49. Karimbux NY, Nishimura I. Temporal and spatial expressions of type XII collagen in the remodeling periodontal ligament during experimental tooth movement. J Dent Res 1995;74:313-318.

50. Oh SP, Griffith CM, Hay ED, Olsen BR. Tissue-specific expression of type XII collagen during mouse embryonic development. Dev Dyn 1993;196:37-46.

51. MacNeil RL, Berry JE, Strayhorn CL, Shigeyama Y, Somerman MJ. Expression of type I and XII collagen during development of the periodontal ligament in the mouse. Arch Oral Biol 1998;43:779-787.

52. Beck F, Tucci J, Russell A, Senior PV, Ferguson MW. The expression of the gene coding for parathyroid hormone-related protein (PTHrP) during tooth development in the rat. Cell Tissue Res 1995;280:283-290.

53. Tenorio D, Hughes FJ. An immunohistochemical investigation of the expression of parathyroid hormone receptors in rat cementoblasts. Arch Oral Biol 1996;41:299305.

54. Philbrick WM, Dreyer BE, Nakchbandi IA, Karaplis AC. Parathyroid hormone-related protein is required for tooth eruption. Proc Natl Acad Sci (USA) 1998;95:1184611851.

55. Schneider LC, Hollinshead MB, Lizzack LS. Tooth eruption induced in grey lethal mice using parathyroid hormone. Arch Oral Biol 1972;17:591-594.

56. Davidovitch Z, Musich D, Doyle M. Hormonal effects on orthodontic tooth movement in cats-a pilot study. Am J Orthod 1972;62:95-96.

57. Bianco P, Fisher LW, Young MF, Termine JD, Robey PG. Expression of bone sialoprotein (BSP) in developing human tissues. Calcif Tissue Int 1991;49:421-426.

58. Fisher LW, Whitson SW, Avioli LV. Matrix sialoprotein of developing bone. J Biolog Chem 1983;258:1272312727.

59. Hunter GK, Goldberg HA. Modulation of crystal formation by bone phosphoproteins: role of glutamic acid-rich sequences in the nucleation of hydroxyapatite by bone sialoprotein. Biochem J 1994;302:175-179.

60. Liu F, Malaval L, Gupta AK, Aubin JE. Simultaneous detection of multiple bone-related mRNAs and protein expression during osteoblast differentiation: polymerase chain reaction and immunocytochemical studies at the single cell level. Dev Biol 1994;166:220-234.

61. Sodek J, Chen J, Kasugai S, et al. Elucidating the functions of bone sialoprotein and osteopontin in bone formation. In: Slavkin H, Price P, eds. Chemistry and Biology of Mineralized Tissues. Amsterdam: Excepta Medica; 1992:297-307.

62. Sodek J, Chen J, Kasugai S, et al. Sialoproteins in bone remodelling. In: Davidovitch Z, ed. The Biological Mechanisms of Tooth Movement and Craniofacial Adaption. Columbus, OH: The Ohio State University College of Dentistry; 1992:127-136.

63. Oldberg A, Franzen A, Heinegard D, Pierschbacher M, Ruoslahti E. Identification of a bone sialoprotein receptor in osteosarcoma cells. J Biol Chem 1988;263:1943319436.

64. McKee MD, Nanci A. Osteopontin at mineralized tissue interfaces in bone, teeth, and osseointegrated implants: ultrastructural distribution and implications for mineralized tissue formation, turnover, and repair. Microscopy Res Tech 1996;33:141-164.

65. Arzate H, Olson SW, Page RC, Narayanan AS. Isolation of human tumor cells that produce cementum proteins in culture. Bone Miner 1992;18:15-30.

66. Goldberg HA, Hunter GK. The inhibitory activity of osteopontin on hydroxyapatite formation in vitro. Ann $N Y$ Acad Sci 1995;760:305-308.

67. Stepan JJ, Presl J, Broulik P, Pacovsky V. Serum osteocalcin levels and bone alkaline phosphatase isoenzyme after oophorectomy and in primary hyperparathyroidism. $J$ Clin Endocrinol Metab 1987;64:1079-1082.

68. Ducy P, Desbois C, Boyce B, et al. Increased bone formation in osteocalcin-deficient mice. Nature 1996; 382:448-452.

69. Nohutcu RM, McCauley LK, Koh AJ, Somerman MJ. Expression of extracellular matrix proteins in human periodontal ligament cells during mineralization in vitro. J Periodontol 1997;68:320-327.

70. Nohutcu RM, McCauley LK, Shigeyama Y, Somerman MJ. Expression of mineral-associated proteins by periodontal ligament cells: in vitro vs. ex vivo. J Periodont Res 1996;31:369-372.

71. Schipani E, Lanske B, Hunzelman J, et al. Targeted expression of constitutively active receptors for parathyroid hormone and parathyroid hormone-related peptide delays endochondral bone formation and rescues mice that lack parathyroid hormone-related peptide. Proc Natl Acad Sci (USA) 1997;94:13689-13694.

72. Philbrick WM, Dreyer BE, Wysolmerski JJ, Broadus AE. Genetic rescue of the extra-skeletal phenotypic features of the PTHrP-null mouse. J Bone Miner Res 1997; 12:s161.

73. Somerman MJ, Young MF, Foster RA, Moehring JM, Imm G, Sauk JJ. Characteristics of human periodontal ligament cells in vitro. Arch Oral Biol 1990;35:241-247.

74. Castoldi M, Pistone M, Caruso C, et al. Osteoblastic cells from rat long bone. II: Adhesion to substrata and integrin expression in primary and propagated cultures. Cell Biol Int 1997;21:7-16.

75. Somerman MJ, Shroff B, Foster RA, Butler WT, Sauk JJ. Mineral-associated adhesion proteins are linked to root formation. Proc Finn Dent Soc 1992;88 (Suppl. 1):451 461.

76. Grzesik WJ, Robey PG. Bone matrix RGD glycoproteins: immunolocalization and interaction with human primary osteoblastic bone cells in vitro. $J$ Bone Miner Res 1994;9:487-496.

77. Caffesse RG, Quinones CR. Polypeptide growth factors and attachment proteins in periodontal wound healing and regeneration. Periodontol 2000 1993;1:69-79.

Send reprint requests to: Dr. M.J. Somerman, Department of Periodontics/Prevention/Geriatrics, University of Michigan School of Dentistry, Ann Arbor, MI 48109-1078. Fax: 734/763-5503; e-mail: somerman@umich.edu

Accepted for publication May 20, 1999. 